\title{
THE PLACE AND ROLE OF THE CONGRESSES OF SOVIETS IN SOCIO-ECONOMIC PROCESSES IN THE TURKESTAN ASSR(1917-1924)
}

\author{
Muminov Husanboy Madaminjonovich \\ Docent Andijan State University, Uzbekistan
}

\section{RESUME}

Muminov Husanboy Madaminjonovich

The place and role of the congresses of Soviets in socio-economic processes in the Turkestan ASSR(19171924)

\section{ABSTRACT}

The article provides information on the activities of the Turkestan Congress of Soviets that determined the main milestones in the socio-economic development of the Turkestan Autonomous Soviet Socialist Republic from 1917 to 1924.

KEYWORDS: - Turkestan ASSR, the congresses of soviets, Turkestan regional congress of soviets of workers' and soldiers' deputies, The Council of People's Commissars of Turkestan, the Central Economic Council.

\section{INTRODUCTION}

Thanks to independence, we have the opportunity to radically reform our history, to study and teach it objectively and truthfully, in terms of justice and history, based on available resources. During the years of independence, on the basis of available sources, great attention is paid to the study of socio-economic processes that took place at different stages of our past history. In particular, the issue of socio-economic processes in the Turkestan ASSR, which operated in 1917-1924, is one of the most pressing issues today.

An analysis of the available sources shows that the materials of the congresses of the Turkestan ASSR Soviets are an important source in the study of this issue and serve as an official document. Through these materials it is possible to analyze the social changes that have taken place in the republic. From 1917 to 1924, 12 congresses of the Soviets of the Turkestan ASSR were held. The congresses of the Turkestan Soviets functioned in the form of plenary sessions, and important issues related to the socio-economic life of the republic, as well as the political and cultural spheres, were considered. These processes include the following.

On April 7-15, 1917 in Tashkent ("House of Freedom") the first Regional Congress of Soviets of workers' and soldiers' deputies was held $\mathbf{1}$. During its activity, the Congress decides to divide

\footnotetext{
${ }^{1}$ Наша газета. 1917. 7 апреля; $\breve{У ̆}_{3}$ МА Ф. И1044,1-рўйхат, 2-йиғ ма жилд, 330-варақ .
} 
CURRENT RESEARCH JOURNAL OF HISTORY 2(12): 01-05, December

2021

DOI: https://doi.org/10.37547/history-crjh-02-12-01

ISSN 2767-472X

(C2021 Master Journals

Crossref do

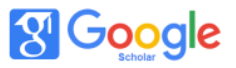

Accepted 04 ${ }^{\text {th }}$ December, 2021 \& Published 09th December, 2021

into sections and conduct business. On this basis, from April 8, organizational, land, labor, trade, military and Muslim sections will be established $^{2}$. On April 12, the report of the economic and trade section discussed the management of existing farms and control over trade organizations, the organization of state trade and the sale of basic necessities, transport, the fight against alcoholism, the fight against trafficking ${ }^{3}$.

Discussed in the report of the working section on April 15, it made the necessary decisions: on the establishment of "conciliation rooms" to resolve disputes between workers and employers on the issue of workers, the introduction of an 8-hour workday, a ban on child labor (under 16), men and women. achieving women's equality ${ }^{4}$. The land issue was left to the Constituent Assembly. Arbitrary and violent seizure of any land was prohibited.

From September 30 to October 10, 1917, the second Regional Congress of Soviets of workers' and soldiers' deputies was held in Tashkent ${ }^{5}$. On November 15-22, the third Regional Congress of Turkestan soviets was held worked ${ }^{\mathbf{6}}$. However, organizational and political issues were on the

$2 \breve{У ̆}_{3}$ МА Ф. И-1044,1-рўйхат, 45-йиғ ма жилд, 2варақ .

$3 \breve{~}_{3}$ МА Ф. И-1044, 1-рўйхат, 2-йиғ ма жилд, 340варақ .

4 Ў МА Ф. И-1044, 1-рўйхат, 45-йиғ ма жилд, 3031-варақ лар.

5 Съезды Советов РСФСР и автономных республик РСФСР. Сборник документов.(19171922 гг). Т.1. -М.: Юридическая литература, 1959. - C.244.

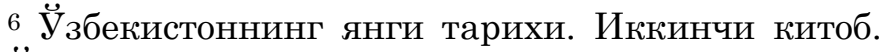
Ўзбекистон совет мустамлакачилиги даврида // Масъул мух аррир: М.Жўраев /. -Т.: Шарқ , 2000. -Б. 47-48. agenda of these congresses.

The fourth Extraordinary Congress of soviets of workers' and soldiers' deputies held in Tashkent on January 19-26, 1918 ${ }^{7}$. They discussed the financial situation of the Soviets, unemployment and the fight against it, the demobilization of the army, the issue of land committees, and made decisions on the financial situation, irrigation (irrigation of Mirzachul) and the establishment of land committees ${ }^{8}$.

The 5th Congress of All Turkestan Soviets was held from April 20 to May 1, 1918 in the House of Freedom in Tashkent ${ }^{9}$. The Congress establishes the following agenda on socio-economic issues: Report of the People's Commissars, i.e. nationalization of industrial enterprises (report on the cotton and mining industry at the Congress on this issue); fight against hunger, unemployment, epidemics, crime; reorganization of the water committee $\mathbf{1 0}$.

On April 23-26, 1918, the Congress discussed issues such as the nationalization of industrial enterprises, the progress of rail transport, the implementation of land and water measures, military construction, the state of food in Turkestan 11.

The VI Extraordinary Congress of Soviets of the Turkestan ASSR was held in Tashkent on October 5-14. Its agenda included the economic situation

\footnotetext{
7 Протоколы заседаний Краевого съезда Советов солдатских и рабочих депутатов (18 января - 26 января 1918 г). -Т.: 1918.

8 «Наша газета». 23 января 1918 г.

$9 \breve{У ̆}_{3}$ МА Ф. Р-17, 1-рўйхат, 1-йиғ ма жилд, 1варақ.

$10 \breve{У ̆}_{3}$ МА Ф. Р-17, 1-рўйхат, 1-йиғ ма жилд, 2варақ .

11 Ўзбек Совет Энциклопедияси. Т.11. -Т.: $\breve{У ̆}_{3}$ СЭ Бош нашр., 1978. -Б. 376.
} 
CURRENT RESEARCH JOURNAL OF HISTORY 2(12): 01-05, December

2021

DOI: https://doi.org/10.37547/history-crjh-02-12-01

ISSN 2767-472X

(C2021 Master Journals

Crossref do

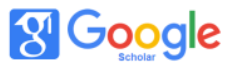

Accepted 04 th December, 2021 \& Published 09 ${ }^{\text {th }}$ December, 2021

and economic policy of the republic, the state budget and financial policy of the Turkestan ASSR, and other issues ${ }^{\mathbf{1 2}}$. Decisions were made at the congress on economic construction, development of cotton growing, strengthening labor discipline.

On March 7, 1919, the VII Extraordinary Congress of Soviets of the Turkestan ASSR opened in Tashkent ${ }^{13}$. The agenda includes economic policy and economic situation of the Turkestan ASSR; economic issues such as the state budget and the financial policy of the republic ${ }^{\mathbf{1 4}}$. The Congress decides to divide it into 10 sections. They formed the sections of national economy, finance, food, land affairs, labor, military, health, public education, justice and organizational-political. Later, a national section will be formed. The reports of the sections will be considered at the Congress. In particular, the national economy section considers it necessary to: a) expand the area under cotton; b) providing cotton farmers with money and nature (products); c) to take all measures against the elimination of the invading gang in Fergana before the cotton harvest; g) request the Center to continue to provide assistance to Turkestan in kind; d) Prompt publication of a decree on land norms in Turkestan by the Commissariat of Land Affairs. Land Affairs (Agriculture) Section of the Congress Irrigation, Crops measures to expand the area, make decisions on improving the activities of the Commissariat for Land Affairs.

The VII Congress of Turkestan Soviets abolishes

$12 \ddot{У ̆}_{3}$ МА Ф. Р-17, 1-рўйхат, 3-йиғ ма жилд, 16варақ .

13 Уразаев Ш.З. Туркестанская АССР и ее государственно-правовые особенности. -Т.: Госиздат УзССР, 1958. -С. 50.

$14 \breve{У}_{3}$ МА Ф. Р-17, 1-рўйхат, 19-йиғ ма жилд, 59варақ . the holidays of workers and employees ${ }^{\mathbf{1 5}}$. This situation had a negative impact on the lifestyle of the population. The Congress decided to take into account the entire male and female population of the republic (from 16 to 55 years). The main purpose of this event was to send them to work in industries where there was a shortage of manpower in the future. The congress ended on March 31.

The VIII Congress of Soviets of the Turkestan ASSR was opened on September 6, 1919 in Tashkent. The congress lasted until October 4 . The Congress organizes its activities and is divided into economic, defense, cultural and educational and organizational sections ${ }^{\mathbf{1 6}}$. Despite the fact that the agenda of the Congress was mainly organizational and political issues, the activities of the economic section on economic issues differed. In particular, this the section will hold 21 meetings from 8 September to 30 September. The section listens to and discusses the reports of a number of commissariats, local Soviet executive committees. The section discusses the establishment of the Economic Council, which will conduct all economic policy in the Turkestan ASSR. It also proposes a number of measures to regulate trade-related activities and to implement a monopoly on bakery products. The Presidium of the Congress, on the basis of the evidence provided by the section, provides guidance on the elimination of existing shortcomings in the practice of monopoly on bakery products.

15 Тарих шох идлиги ва сабоқ лари. Чоризм ва совет мустамлакачилиги даврида Ўзбекистон миллий бойликларининг ўзлаштирилиши // Масъул мух аррир: Д.А. Алимова./. -Т.: Шарқ , 2001. -Б. 177.

16 Ў 3 МА Ф. Р-17, 1-рўйхат, 34-йиғ ма жилд, 149150-варақ лар. 
CURRENT RESEARCH JOURNAL OF HISTORY 2(12): 01-05, December

2021

DOI: https://doi.org/10.37547/history-crjh-02-12-01

ISSN 2767-472X

(C2021 Master Journals

Crossref do

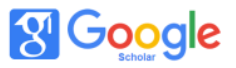

Accepted 04 th December, 2021 \& Published 09 ${ }^{\text {th }}$ December, 2021

The IX Congress of Soviets of the Turkestan ASSR began its work on September 19, 1920 in Tashkent. The following economic issues will be on the agenda of this congress, which will run until September 25: Economic policy of Turkestan: a) the Central Economic Council; b) Additional report on transport; c) Food Commissariat; d) Commissariat of Land Affairs; e) Reports of the Financial Commission. The congress was divided into four sections. They organized organizational, land policy, food and finance sections ${ }^{\mathbf{1 7}}$.

The land issue was discussed and a land reform plan was developed. Based on the land decree, the congress adopts the law. The law abolishes private ownership of land and declares all land to be public property. After hearing the report of the Food Commission, the Congress decided to maintain the state monopoly on food products, fixed prices and food distribution. At the meetings, the Finance section listens to the report of the Commissariat of Finance and develops a resolution on financial measures ${ }^{\mathbf{1 8}}$. The reports of the Labor and Peasant Inspectorate, the Interior, Education, Labor and Social Welfare, Justice, Health, Post and Telegraph Commissions, as well as the Central Statistical Office were submitted to the Congress in writing. A total of fifteen reports were considered at this congress, and important instructions and decisions on these issues will be developed ${ }^{19}$.

$17 \breve{У ̆}_{3}$ МА Ф. Р-17, 1-рўйхат, 39-йиғ ма жилд, 1варақ .

18 Ў МА Ф. Р-17, 1-рўйхат, 39-йиғ ма жилд, 140а-варақ .

19 Материалы к IX съезду Советов Рабочих, Крестьянских, Дехканских, Казачьих и Красноармейских Депутатов Туркестанской Социалистической Советской Республики. -Т.:
The IX Congress of Soviets of the Turkestan ASSR decided to develop a unified three-year economic plan of the republic. The plan covers various sectors of the economy, including transport, cotton, silk, fuel, oil and coal, chemical industry, hydropower, irrigation, livestock, etc ${ }^{\mathbf{2 0}}$.

The X Congress of Soviets of the Turkestan ASSR was opened on August 21, 1921 in Tashkent ${ }^{21}$. The work of the Congress lasted until August 25, and its agenda included economic policy, land policy, important socio-economic issues such as food tax and cooperation were raised.

On December 2-6, 1922, the XI Congress of Soviets of the Turkestan ASSR was held. Despite the fact that the agenda of the congress focuses on the political sphere, it also considers economic issues. In particular, the congress listened to the reports of the Turkestan CRC, PCS and reports on economic issues, and held talks on issues. The congress will also consider the issue of land and water reform and identify the main tasks of the reform.

January 1, 1924 XII Congress of Soviets of the Turkestan ASSR opened in the theater building "Sverdlova" in Tashkent ${ }^{22}$. The agenda includes the report of the Council of People's Commissars and the Economic Council of Turkestan; Financial and tax issues; The People's Commissariat for Land Affairs reported; Socio-economic and other issues related to the development of cotton, such as the report of the Committee on Cotton

1920.

$20 \breve{У ̆}_{3}$ МА Ф. Р-17, 1-рўйхат, 39-йиғ ма жилд, 183190-варақ лар.

$21 \ddot{\mathbf{y}}_{3}$ МА Ф. Р-17, 1-рўйхат, 44-йиғ ма жилд, 1варақ .

22 Ў 3 МА Ф. Р-17, 1-рўйхат, 116-йиғ ма жилд, 10варақ . 
CURRENT RESEARCH JOURNAL OF HISTORY 2(12): 01-05, December

2021

DOI: https://doi.org/10.37547/history-crjh-02-12-01

ISSN 2767-472X

(C2021 Master Journals

Crossref do

81 Google

Accepted 04 ${ }^{\text {th }}$ December, 2021 \& Published 09th December, 2021

Affairs $^{23}$.

According to the agenda of the congress, the report of the Central Election Commission, the Central Election Commission and the Economic Council of Turkestan was considered, and the Center paid great attention to meeting the needs and requirements of Turkestan. According to the reports, the speakers pointed out the increase in industrial production in the country and the state of growth in the industrial management system, and also explained the problems in this area (lack of exchange tools, lack of accounting, increased additional costs, etc.). A single resolution was adopted on the basis of the discussions. It tasked the republican government and the CRC with implementing a system of measures developed by the Congress in recent years to improve the political structure of the Soviets, education, agriculture, industry, cooperation and trade management, finance, transport, planning, and the living standards of workers.

At the Congress, the People's Commissariat of Finance will report on the improvement of the economic and financial situation of the Turkestan ASSR. At the same time, it is noted that the weak state of the local budget, economic activities lag behind the state budget. The Congress will develop measures to improve the work and financial condition of the People's Commissariat of Finance.

Based on the report of the People's Commissariat for Land Affairs, the congress discussed the issue of rapid land use in two regions of Turkestan (ie, sedentary areas: Fergana, Samarkand, Syrdarya regions and vacant lands: Yettisuv region).

Reports on cotton growing at the congress show that the area under cotton has tripled over the

$23 \breve{У ̆}_{3}$ МА Ф. Р-17, 1-рўйхат, 101-йиғ ма жилд, 11варақ . year, and the issue of improving the material conditions of cotton growers will be discussed ${ }^{\mathbf{2 4}}$. In conclusion, political, socio-economic and cultural issues were discussed at the congresses of the Soviets of the Turkestan ASSR, which functioned from 1917 to 1924. Decisions made on the basis of discussions provided changes in all areas of the country.

\section{ReFERENCES}

1. Наша газета. 1917. 7 апреля; Ўз МА Ф. И1044,1-рўйхат, 2-йиғма жилд, 330-варақ.

2. Ўз МА Ф. И-1044,1-рўйхат, 45-йиғма жилд, 2-варақ.

3. Ўз МА Ф. И-1044, 1-рўйхат, 2-йиғма жилд, 340-варақ.

4. Ўз МА Ф. И-1044, 1-рўйхат, 45-йиғма жилд, 30-31-варақлар.

5. Съезды Советов РСФСР и автономных республик РСФСР. Сборник документов.(1917-1922 гг). T.1. -М.: Юридическая литература, 1959. -С.244.

6. Ўзбекистоннинг янги тарихи. Иккинчи китоб. Ўзбекистон совет мустамлакачилиги даврида // Масъул мухаррир: М.Жўраев /. -Т.: Шарқ, 2000. -Б. 47-48.

7. Протоколы заседаний Краевого съезда Советов солдатских и рабочих депутатов (18 января - 26 января 1918 г). -Т.: 1918.

8. «Наша газета». 23 января 1918 г.

9. Ўз МА Ф. Р-17, 1-рўйхат, 1-йиғма жилд, 1варақ.

10. Ўз МА Ф. Р-17, 1-рўйхат, 1-йиғма жилд, 2-

24 Бюллетень XII-го Всетуркестанского съезда Советов рабочих, дехканских и красноармейских депутатов. № 1-11. Т.1924. 
CURRENT RESEARCH JOURNAL OF HISTORY 2(12): 01-05, December

2021

DOI: https://doi.org/10.37547/history-crjh-02-12-01

ISSN 2767-472X

(C)2021 Master Journals

\section{Crossref doi gi Google}

Accepted 04 ${ }^{\text {th }}$ December, 2021 \& Published 09th December, 2021

варақ.

11. Ўзбек Совет Энциклопедияси. Т.11. -Т.: ЎзС Бош нашр., 1978. -Б. 376.

12. Ўз МА Ф. Р-17, 1-рўйхат, 3-йиғма жилд, 16-варақ.

13. Уразаев Ш.3. Туркестанская АССР и ее государственно-правовые особенности. Т.: Госиздат УзССР, 1958. -С. 50.

14. Ўз МА Ф. Р-17, 1-рўйхат, 19-йиғма жилд, 59-варақ.

15. Тарих шохидлиги ва сабоқлари. Чоризм ва совет мустамлакачилиги даврида Ўзбекистон миллий бойликларининг ўзлаштирилиши ?] Масъул мухаррир: Д.А. Алимова.?. -Т.: Шарқ, 2001. -Б. 177.

16. Ўз МА Ф. Р-17, 1-рўйхат, 34-йиғма жилд, 149-150-варақлар.

17. Ўз МА Ф. Р-17, 1-рўйхат, 39-йиғма жилд, 1-варақ.

18. Ўз МА Ф. Р-17, 1-рўйхат, 39-йиғма жилд, 140а-варақ.

19. Материалы к IX съезду Советов Рабочих, Крестьянских, Дехканских, Казачьих и Красноармейских Депутатов Туркестанской Социалистической Советской Республики. -Т.: 1920.

20. Ўз МА Ф. Р-17, 1-рўйхат, 39-йиғма жилд, 183-190-варақлар.

21. Ўз МА Ф. Р-17, 1-рўйхат, 44-йиғма жилд, 1-варақ.

22. Ўз МА Ф. Р-17, 1-рўйхат, 116-йиғма жилд, 10-варақ.

23. Ўз МА Ф. Р-17, 1-рўйхат, 101-йиғма жилд, 11-варақ.

24. Бюллетень XII-го Всетуркестанского съезда Советов рабочих, дехканских и красноармейских депутатов. № 1-11. 